DOI: https://doi.org/10.3126/njdrs.v15i0.31605

\title{
Impacts of Climate Change in Nepalese Agriculture
}

\author{
Suman Kumar Shrestha* and Gem Prasad Gurung, PhD** \\ *Asst. Prof., Tribhuvan University, Sanothimi Campus, Bhaktapur \\ **Assoc. Prof., Tribhuvan University, Sanothimi Campus \\ Email for correspondence: shresthasuman1971@gmail.com and gem_gurung@yahoo.com
}

\begin{abstract}
This paper presents impact of climate change in agriculture and adaptation strategies applying by the farmers. In doing so, secondary data and information as well as document review methods are applied. The study found that climate change has affected the different sectors such as agriculture and non-agriculture. Especially agriculture is the more affected than non-agricultural sector. The major crops production trend is gradually decreasing due to the negative impact of climate change. Comparatively, climate change has more affected in the Himalayas and hilly region than Tarai. Owing to that farmers are applying different adaptation strategies for minimizing the climate change impact on productions. However, federal governments must prepare and implement the attractive affirmative policies that are needed to motivate small farmers living in Mountain, Hill and Tarai region.
\end{abstract}

Key words: Climate change, agricultural impact, adaptation strategies, cereal crops

\section{Background}

Nepal is an agrarian country. According to Geographical division, it is divided into Mountain, Hill and Tarai region. The climate in Nepal varies from sub-tropical to alpine within a short distance due to tremendous variation in topography and altitude (60 to 8,848 m) (CBS, 2016). These factors along with direction of mountain slope have created numerous micro-environments. Alpine, cool temperate, warm temperate, subtropical and tropical climates prevail in Nepal. Climate change is a burning issues of the world in the developed and developing countries. It effects the agriculture sectors and non- agriculture sectors. It affects more agriculture sector than non-agriculture sectors. Nepal is a developing country and the climate directly effect in the agriculture. Impact rate of climate change gradually increase. The average climate is $0.06^{\circ} \mathrm{C}$ but increase rate is also different in Terai and Himalays region from $0.04^{\circ} \mathrm{C}$ to $0.08^{\circ} \mathrm{C}$ respectively (Shrestha, 1999). Climate Risk Index 2018 ranked of Nepal 26th in the global list of is the most vulnerable countries to climate change between 1997 and 2016. Climate change scenarios mean annual temperatures are projected to increase $1.3-3.8^{\circ} \mathrm{C}$ by 2060 and $1.8-5.8^{\circ} \mathrm{C}$ by 2090 but annual precipitation is projected to decrease 10 to 20 percent nationwide.

Nepal is an agriculture country in which two- third of the population depends on its and it contribute almost 34 percent of the GDP (MoF, 2014). Due to climate change production rate and quality is decreased of crops and increased temperatures (thus evaporation). Therefore, decreased and more uncertain rainfall, and increased chemical fertilizers presence of pests and diseases to increase the production. Due to the excessive chemical fertilizer, excessive pollutants of industry, mismanagement of settlement etc. the temperature is continuous increased and impact in climate. Due to climate change 
Nepal still faces food security issues. We have not enough resource to get the information about the climate change and adaptation. Barriers that prevent Nepali farmers from making significant progress on climate change adaptation include limited access to knowledge informed the climate change. There are limited access getting source of information about climate change and early warning system of weather it could help them, anticipate weather events and better manage their crops. Farmer use chemical and organic seeds and fertilizer for the increase of production. They gradually discourage of the chemical fertilizers. They are conscious about health.

Therefore, they are gradually replaced of chemical fertilizer and increase the organic fertilizer. Moreover, farmers typically have limited knowledge of climate-smart agriculture practices, such as soil fertility, disease-resistant crop care, and irrigation practices, due to weak extension services. Otherwise, most of the Nepalese farmers have limited access to high quality inputs. These include improved (more climate resilient and high yielding) seed varieties and fertilizers, modern machinery, and markets, as links with agribusiness tend to be rare and weak in most crops. Knowledge of climatesmart agriculture practices, such as soil fertility, disease-resistant crop care, and irrigation practices, due to weak extension services. Most of the Nepalese farmers have limited access to high quality inputs. These include improved (more climate resilient and high yielding) seed varieties and fertilizers, modern machinery, finance and markets, as links with agribusiness tend to be rare and weak in most crops. These barriers prevent significant private investment in adaptation within Nepal's agriculture sector, despite the enormous potential that private actors-big farmers, processors, and input suppliers.

\section{Objectives}

- To find out the impact of climate change in agriculture

- To identify the use of adaptation strategies of climate change

\section{Methods and Materials}

The research methodology is the process of doing research. Kitchen and Tate (2000) observes that it is a coherent set of rules and procedures which can be used to investigate or way for solve the problem. Also, methodology guides the process how to collect data and its analysis and interpretation as well. The data is taken document review related to impact of climate change in agriculture in Nepal. This paper is based on the review of different national and international papers related to agriculture and it's being impact by climate change. The study is based on the secondary data regarding the climate change and their impact of crops was collected. The national documents, policies, plan, strategies, brochure, booklets, reports, program, projects, research results and published reports related to agriculture and climate change were collected from the concerned directorates, office, projects as well as official websites

\section{Discussion and Results: Impact of Climate Change}

Nepal is an agriculture country. Majority of the people involved in agriculture. Majorities of the farmers are performing integrated farming system in which crops and livestock are interdependent. Especially in terrain region agriculture production system has going to change. They used modern technology and information for production of the crops and vegetables. Due to modern technology and information farming has increased the productivity of the cultivable land. Such type of farming helps to maintain the fertility of soil by using machines and technology to create soil conditions appropriate for plant growth with minimal soil loss, drought, insects, diseases and other threats.

Nepalese Journal of Development and Rural Studies, Volume 15, 2018 
The use of science and modern technology to produce hybrid seeds, pesticides and fertilizers have increased the agricultural productivity, which is a good aspect, however, the nutrition value of such food has decreased compared to the traditionally grown crops. The major problems are created by fertilizers and pesticides which have long term effects on fertility of soil and consumers health. Many fertilizers create disturbance in ecosystem as well. Also, the production of crops like corn, rice and wheat has increased by the introduction of bio technological advancement in seed production and growth. Agriculture is the main economic source of Nepal. It is depends upon the more than 66 percent population ( $>70 \%$ of women population) and contributes 34 percent GDP Product of the country (CBS, 2014; MoF, 2018). The total agricultural land of the country is $4,243,160$ ha (29.7\% of total area) with per capita availability of 0.082 ha and households owning less than 0.5 ha 51 percent (MoAD, 2014).

Nepal is one of the least developed countries in the world with low GDP of US\$562 (CBS, 2012). It is estimated that approximately 25 percent of the populations live below the poverty line as of US\$ 1.25 a day (NPC, 2010). Global warming and climate change are the greatest concerns since they affect human being and the whole ecosystem. Agriculture, livelihood, sustainable management of natural resources and food security are inextricably linked within the development climate change challenges of the twenty first century (FAO, 2012). Due to the climate change will not only amplify the existing risk that the nature and humans already are influenced by but also keep creating new risks for all systems ( IPCC, 2014). The research analysis of climatic factors provides the level of association between cereal crop and climate change. These days due to extreme climatic conditions such as persistent rise in mean annual temperature in Nepal and increase in precipitation have almost adverse impacts of various elements of agricultural production system (Lohani, 2007). Drought is the major reason of uncertainty in food production in Nepal and it disturbs social harmony by creating water-use conflicts (Thompson, 2008). On the basis of the experience gradually decrease the rainfall and increase in temperature will have a negative impact in cereals yield (Bhandari, 2013). Nepal is experiencing various natural disasters such as floods, hailstones, landslides, mass movement, soil erosion, and avalanche, there by affecting the agriculture system (Barlet, Bharati, Pant, Hosterman $\&$ McCornik, 2010). In such areas, the majorities of farmers rely on rain fed crops and follow labor intensive traditional methods for farming (Pokhrel \& Thapa, 2007).

\section{Land Use Type}

Land is free gifted by nature. The land used in different purpose. Which is the base of human being? The lands aren't equal importance. The different types of land used in different Purpose which is given below (Table 1). 
Table1. Land Use Type

\begin{tabular}{lcc}
\hline Type & Land (ha.) & Percentage \\
Forest & $6,306,460$ & 42.5 \\
a. Forest land & $5,618,052$ & 37.8 \\
b. Shrubs & 688,408 & 4.7 \\
Agriculture & $3,954,915$ & 26.6 \\
a. Cultivated & $2,968,017$ & 20.0 \\
b. Uncultivated & 986,898 & 6.6 \\
Pastures & $1,757,345$ & 11.8 \\
Others (Snow, lake, urban area etc.) & $2,836,322$ & 19.1 \\
Total & $\mathbf{1 4 , 8 5 5 , 0 4 2}$ & $\mathbf{1 0 0 . 0}$ \\
\hline
\end{tabular}

The table shows that forest covered the highest area which is 42.5 percent and agriculture land covered 26.6 percent. Then pasture land covered 11.8 percent and others (Snow, lake, urban area etc.) also covered 19.1 percent. Only 26.6 percent land is agriculture but 20.0 percent cultivated and 6.6 percent uncultivated. Among the two third people involve in agriculture but couldn't able to satisfied production. And year by year we import the food crops. Due to subsistence agriculture farming, lack of subsidy, lack of capital etc.

\section{Land Holding by Farmers}

The different size of land used for the crops production in Nepal. All the people don't hold the equal land. The land lord hold the big size of land and poor people hold the small size of land. Nepal is a developing country and majority of the people hold the small size of land. The different categorization of households holds the based on the size of land ownership which is given below:

Table 2. Categorization of Households based on the size of land Ownership

\begin{tabular}{lccc}
\hline Types of holdings & Household number & Area (h.) & Percentage \\
Under 0.1 hactor & 471087 & 23195.8 & 12.29 \\
0.1 to 0.5 hactor & 1631460 & 464882.7 & 42.58 \\
0.5 to 1 hactor & 984022 & 695060.1 & 25.68 \\
1 to 5 hactor & 732736 & 1258096.3 & 19.12 \\
5 to 10 hactor & 10744 & 69177.1 & 0.28 \\
Above 10 hactor & 1054 & 15227.2 & 00.02 \\
Total & $\mathbf{3 8 3 1 0 9 3}$ & $\mathbf{2 5 2 5 6 3 9 . 2}$ & $\mathbf{1 0 0}$ \\
\hline
\end{tabular}

The table 2 shows that the categorize of household based on fragmentation of land, the land holding capacity per household. The 471087 households holding the under 0.1 hactor land and the area is 0.92 percent. The 732736 household holding the 1 to 5 hactor and which is covered the highest area of the total land 49.81 percent and 1054 household holding the above the 10 hactors which is the lowest area of the total lands 0.60 percent. Therefore the data shows that majority of the household holding the 1 to 5 hactors and minority of the households holding the above the 10 hactors. 


\section{Cereal Crops Production}

Cereal Crop production trends are different in Nepal. There are three types of ecological region in Nepal. Rice is the main food crop which could face going to risk due to changes in the pattern of rainfall, stream flows, a more intense and potentially erratic monsoon rainfall and the impacts of flooding. Cereal crops including rice, wheat, maize, millet, barely and buckwheat is the mainstay of Nepal's agriculture. Approximately 64 percent of the cultivated areas are heavily dependent on monsoon rainfall and its affect the agricultural production significantly, especially rice yields (NAPA, 2010). The impacts of climate change more affected in the mountain and Himalayas as compared to plain areas (Pokhrel \& Pandey, 2011). In the high altitude, most of the population depends on subsistence agriculture. Due to the land feature, they couldn't use commercial grain farming in Hilly and Himalayas region. But terai is the plain area and possible used commercial grain farming. Therefore, these days Nepal also gradually increases the use of commercial grain farming. The agricultural production affected by the water-induced disaster such as floods, landslide, inundation and land cutting. Cereal crops production is trends have been given below:

Table 4. Cereals Affected by Natural Disaster (in ha)

\begin{tabular}{lcccc}
\hline Cereals & FY 2007 & FY 2008 & FY 2009 & FY 2010 \\
Paddy & 88800 & 30873 & 92000 & 567 \\
Maize & 4271 & 549 & 1700 & 563 \\
Millet & 1451 & 3.2 & 0 & 13 \\
Total & $\mathbf{9 4 5 2 2}$ & $\mathbf{3 1 4 2 5 . 2}$ & $\mathbf{9 3 7 0 0}$ & $\mathbf{1 1 4 3}$ \\
\hline
\end{tabular}

The table 4 has shown the cereal crops production trends in Nepal. The area of paddy production is 88800 hactor in FY 2007 and 567 haactor in FY 2010. Maize also decreasing rate maize production is 4271 hactor in FY 2007 and 563 haactor in FY 2010. The area of millet production trends is 1451 haactor in FY2007 and 13 hactor in FY 2010. Therefore, the data shows that the production area gradually decrease Due to climate change and remittance the cultivated land going to barren land. Lack of the subsidy by the government they invest high but returned is low. The government provides the subsidy to the farmer but the real farmer don't access to get it. The artificial farmer gets the subsidy. Therefore, the real farmer don't attract in the agriculture. But some of the farmer has changed their food crops to cash crops.

\section{Area and Production of Crops}

The trends of crops production and use of land has different in Nepal. In the earlier time production has increased and late time it is going too decreased. There are many causes to be decreased. The trends of crop production and area have given below (Table 5). 
Table 5. Area and Production of Crops (Production in 1,000 Metric Tons)

\begin{tabular}{lcccccc}
\hline Crop & Area & $\begin{array}{c}\text { Prod. } \\
\text { 1990/91 }\end{array}$ & Are & $\begin{array}{c}\text { Prod. } \\
\mathbf{1 9 9 1 / 9 2}\end{array}$ & Area & $\begin{array}{c}\text { Prod. } \\
\mathbf{1 9 9 2 / 9 3}\end{array}$ \\
Cereal Crops & & & & & & \\
Paddy & 1,455 & 3,502 & 1,412 & 3,223 & 1,262 & 2585 \\
Maize & 758 & 1231 & 774 & 1205 & 775 & 1291 \\
Wheat & 593 & 836 & 571 & 779 & 614 & 765 \\
Millet & 208 & 232 & 198 & 229 & 202 & 237 \\
Barley & 30 & 28 & 30 & 28 & 30 & 28 \\
Total & 3044 & 5829 & 2965 & 5464 & 2883 & 4906 \\
Cash crops & & & & & & \\
Oilseed & 156 & 92 & 155 & 88 & 165 & 94 \\
Potato & 84 & 738 & 85 & 733 & 87 & 733 \\
Sugarcane & 32 & 1106 & 37 & 1291 & 38 & 1366 \\
Pulses & - & - & 262 & 155 & 262 & 155 \\
Total & $\mathbf{3 3 1 6}$ & $\mathbf{7 7 6 5}$ & $\mathbf{5 3 9}$ & $\mathbf{2 2 6 7}$ & $\mathbf{5 5 2}$ & $\mathbf{2 3 4 8}$ \\
\hline & & & & & & $(\mathbf{M 0 A} \mathbf{1 9 9 3 / 9 4})$
\end{tabular}

The table 5 has given the trends of crop production and use of land. In 1990/91 the paddy production 3502000 metric ton and in 1992/93 has produce the 2585000. Like this, the area also different in 1990/ 91 the crops planted in 1455 hector and in 1992/93 the crop planted in 1262 hector. Others production trend has given in the table. According to table the crop production and plantation land also going to decrease. If such trend will be increased the big problem will come, so the government make the effective policy and implement to solve it.

\section{Climate Change Adaptation Strategies}

Nepal is a developing country. Climate change is a serious problem in developed and developing countries. But it has resulted more effects in developing countries than developed countries due to the adaptation strategies. There are different adaptation strategies adopted by farmer because they have indigenous knowledge and modern knowledge. By understanding the dynamics of poor people's livelihood, we can understand how they will be affected by climate change impacts. How they might respond with the resources, how these conditions can be reflected and built upon for successful adaptation strategies (IUCN, 2012). The Intergovernmental Panel on Climate Change (IPCC, 2014) defined adaptation as "adjustment in natural or human systems in response to actual or expected climatic stimuli or their effects, which moderates harm or exploits beneficial opportunities. In general, adaptation options in agriculture are influenced by number of parameters such as climate, biophysical, socio-political and environmental factors (Aydinalp \& Cresser, 2008). There are traditional, local, national and international strategies adopted for the adjustment.

In 1994, Nepal signed the United Nations Framework Convention on Climate Change (UNFCCC) and also a National Climate Change Policy is in the process of elaboration (Leduc, Shrestha $\&$ Bhattarai, 2008). In the context of the climate change, the government of Nepal has prepared its National Adaptation Programme of Action (NAPA) for adapting to extreme climate events and variability through an extensive country-driven consultative process. It was shared with Parties to the UNFCCC in November 2010 and also prepared a National Framework for Local Adaptation Plan for 
Action (LAPA). The objectives of implementing adaptation actions and integrating climate change into local development planning and implementation (NAPA, 2010). The LAPA Framework ensures that the local process of integrating climate change resilience from local to-national planning is bottom-up, inclusive, responsive and flexible. The government prepared the good policy to reduce the impact of the climate change but the country does not have enough funds to invest on activities. Again related budget depend on the donor support, if donor support don't support for this programme it also effect the programme.

The NAPA programme is not effective as expected due to lack of technical capacity and weak coordination across the government sectors, and also low awareness of climate change. Lack of funding on implementation of adaptive activities on climate change is considered as one of the bottlenecks for agriculture sector in Nepal (OXFAM, 2009). It is estimated that the annual adaptation cost on agriculture will be in the order of US\$ 20,000 (about US\$ 70 per target household) at grassroots (village) scale in Nepal (IIED, 2011). However, this amount will not be adequate in order to carry out adaptation in full scale in the country. In recent years, farmers are concerned about the climatic change and are trying to adapt through technological innovations in response to climate change at their disposal (Charmakar, 2010). Farmers have changed their cropping pattern as per the climatic adjustments and prioritized the use of organic manure rather than chemical fertilizers (Bartlett, Bharati, Pant, Hosterman, \& McCornick, 2010) Warming and rising of temperature in the higher altitude has benefitted some households such as growing maize, and green vegetables (OXFAM, 2009). Improved varieties of seeds are also being introduced in their farming (Chapagain, Subedi \& Paudel, 2009). Majority of the people depends on agriculture it is developed to adapt the climate change and global warming. Mitigation of climate change effects are taken under consideration and various projects are developed for this. The impacts of historic climatic factors trends on crop production helps to identify the possible impacts of future climate, which also reviews the on-going efforts of adaptation and change in production (Lobell \& Field, 2007).

The impacts of climate change on agriculture production are both positive as well as negative, however, the impacts will differ globally (Khanal, 2009). Farm compost is prepared traditionally but weedy grass rather than cover crop farming is found practiced. Cultural and chemical methods are used rather biological for pest and disease control. Inter and multiple cropping systems are rarely found rather crop rotation.

Overall, considering the application of principles of agro-ecology, farmers are found having less exposure due to technological, institutional and policy constraints. So, this is the time to think the related persons and agencies in a serious condition for the agriculture transformation. Chaudhary and Pasa (2015) in this regard, suggested government to transform agriculture system through offering accessible and affordable agriculture education to the economically back warded students whose parents are involving in agriculture sectors. The effects of climate change can never be totally eradicated but they can be minimized through proper planning and policies and can able to adapt according to condition. For this, Government of Nepal has formulated policies regarding climate change with the hope of minimizing these effects. As to conclude, climate change has negative impact on agriculture in the long run. So, this is the time to think in a serious and sustainable way. 


\section{Conclusion}

Climate change is a serious problem in the world. The effects of climate change is the agriculture and non- agriculture sectors. Nepal is a high risk in climate change. Nepal is subjected towards high vulnerability of climate change because it is a developing country. There are different effects of climate change in Nepal such as irregularity in Rainfall pattern, Temperature rise have started to create problems to several farmers of the country. Due to climate change, the carbon dioxide composition has some beneficial impacts to some crops in short period of time. The research used secondary data and documents review. On the basis of secondary data it is find out the cereal crops production including paddy, maize and millet. It find out the gradually decrease the cultivation area of Nepal due to climate change. The effects of climate change can't totally eradicate in once time but it can be minimized through proper planning and policies. For this, Government of Nepal has formulated policies regarding climate change with the hope of minimizing these effects. As to conclude, climate change has negative impact on agriculture in the long run. So, this is the time to think in a serious and sustainable way.

\section{References}

Ministry of Agriculture (MoA). (1993/94). Agricultural statistics of Nepal. Kathmandu: Agricultural Research Council.

Aydinalp, C. \& Cresser, M. S. (2008). The effects of global climate change on agriculture. AmericanEurasian Journal of Agricultural and Environmental Science, 3(5), 672-676.

Barlett, R., Bharati, L., Pant, D., Hosterman, H. \& McCornick, P. (2010). Climate change impacts and adaptation in Nepal (Working Paper No 139). Colombo, Sri Lanka: International Water Management Institute (IWMI).

Central Bureau of Statistics (CBS). (2012). Statistical year book Nepal. Kathmandu: National Planning Commission Secretariat.

Central Bureau of Statistics (CBS). (2011/12). National sample census of agriculture. Kathmandu: National Planning Commission Secretariat.

Central Bureau of Statistics (CBS) (2014). Statistical year book. Kathmandu: National Planning Commission Secretariat.

Central Bureau of Statistics (CBS). (2016). Statistical year book. Kathmandu: National Planning Commission Secretariat.

Chapagain, B. K., Subedi, R., \& Paudel, N. S. (2009). Exploring local knowledge of climate change: some reflections. Journal of Agriculture Environment, 8(1), 106-112.

Charmakar, S. (2010). Exploring existing local adaptation practices and potential strategic options to address climate change impact on biodiversity and its dependents of Nepal. A paper presented on National Adaptation Programme of Action. Kathmandu: Ministry of Environment, Government of Nepal.

Chaudhary, P. K. \& Pasa, R. B. (2015). Agriculture Education for Rural Development in Nepal. Journal of Training and Development, 1, 38-45. Author. doi: https://doi.org/10.3126/jtd.v1i0.13089 Food and Agriculture Organization (FAO). (2012). Climate change impacts on agriculture and food security and disaster risk management as entry point for climate change adaptation. Retrieved from http://www.fao.46 org/docs/up/easypol/778/climate-change_impacts_on_agric_food_security_ 
slides_077EN.pdf.

International Institute for Environment and Development (IIED). (2011). Costing agriculture's adaptation to climate change. Journal of Agriculture Systems, 94(2), 151-64.

Intergovernmental panel on Climate change (IPCC). (2014). Climate change and mitigation (Fourth Assessment Report). Cambridge: Cambridge, University Press.

International Union for Conservation of Nature (IUCN). (2009. Ecosystem-based adaptation (Position Paper for the UNFCCC). Retrieved from http://cmsdata.iucn.org/downloads/iucn position_paper_eba_september_09.pd

Khanal, R. C. (2009). Climate change and organic agriculture. Journal of Agriculture Environment, $10(1), 100-110$.

Kitchen, R., \& Tate, N. J (2000). Conducting research into human geography: Theory, methodology and practice. London: Prentice Hall.

Leduc, B., Shrestha, A., \& Bhattarai, B. (2008). Gender and climate change in the Hindu Kush Himalayas of Nepal. A paper presented in gender and climate change workshop in Dakar, Senegal.

Lobell, D. B., \& Field, C. B. (2007). Global scale climate-crop yield relationships and the impacts of recent warming. Environmental Research Letters, 2. doi:10.1088/1748- 9326/2/1/014002.

Lohani, S. N. (2007). Climate change in Nepal-shall we wait until bitter consequences. Journal of Agriculture Environment, 8(1), 38-45.

Ministry of Finance (MoF). (2014). Economic survey, 2015/16. Kathmandu: Government of Nepal.

Ministry of Finance (MoF). (2018). Macroeconomic update Nepal (Volume 6, No. 1). Kathmandu: Government of Nepal.

Ministry of Agricultural Development (MoAD). (2011/12). Statistical information on Nepalese agriculture. Singha Durbar, Kathmandu: Agri-Business Promotion and Statistics Section.

National Adaptation Programme of Action (NAPA). (2010). Annual report. Retrieved from http://www. moste.gov.np/elibrary?page=3\#.USZNYR3Is1 I Archived2013-11-02.

Nepal National Planning Commission (NPC). (1992). Eighth five year plan (1992-1997). Kathmandu: Government of Nepal.

Nepal National Planning Commission(NPC). (2010). Three year interim plan. Kathmandu: Government of Nepal.

Oxford Committee for Famine Relief (OXFAM). (2009). Even the Himalayas have stopped smiling: Climate change, poverty and adaptation in Nepal. Lalitpur: Oxfam International, Country Programme.

Pokhrel, D. M., \& Pandey, B. (2011). Climate change adaptation: strategic vision in agriculture. Journal of Agriculture Environment, 12(1), 104-12.

Pokhrel, D. M., \& Thapa, G. B. (2070). Are marketing intermediaries exploiting mountain farmer? Journal of Agriculture Systems, 94, 151-164.

Shrestha, A. B. (1999). Maximum temperature trends in the Himalaya and its vicinity: An analysis based on temperature records from Nepal for the period 1971-94. Journal of Climate, 12, 2775-2786. 